\title{
The Eureka Moment? The creation of the British welfare state
}

\begin{abstract}
Martin Powell ${ }^{1}$
Abstract: This article explores when the welfare state was established in Britain. First it examines the definitions of the welfare state, before turning to outline the methods and criteria used in exploring the establishment of welfare states. It then discusses the criteria that have been applied to the British case (expenditure; legislation; content; social citizenship; antithesis of the Poor Law) before critically analysing the arguments for different creation periods for the British welfare state (Old Poor Law; nineteenth century; Liberal reforms; inter-war period; 1945; later periods). It is concluded that while the strongest case and the greatest number of dimensions suggest 1945, in the words of T H Marshall: "we may still be in doubt what was the exact combination of circumstances in Britain in the 1940's which evoked that cry of 'Eureka!'
\end{abstract}

\section{Keywords:}

1. Professor of Health and Social Policy, Health Services Management Centre, University of Birmingham

Address for correspondence: m.powell@bham.ac.uk

Date of first (online) publication: 3rd January 2020 


\section{Introduction}

Despite the academic discipline of Social Administration/ Policy existing for many years (Richard Titmuss was appointed Professor of Social Administration at the London School of Economics and Political Science in 1950), we still appear to lack clear answers to seemingly basic questions such as 'When, How and Why Does a State Become A Welfare State' (Therborn, 1983)? Rather than focusing on all of Therborn's (1983) questions, this article provides a more modest exploration of when was the welfare state established in Britain, given the importance of Britain in welfare state debates (see below). This article first examines the definitions of the welfare state, before turning to outline the methods and criteria used in exploring the establishment of welfare states. It critically examines the different dimensions used by scholars in operationalising the concept of the welfare state (Table 1). It then discusses the criteria that have been applied to the British case, before critically analysing the arguments for different creation periods for the British welfare state. It finds that there are over 20 different conclusions of accounts of the establishment of the British welfare state arrive at rather different conclusions as they draw on different (often implicit) criteria, methods, and evidence (Table 2).

\section{Defining the welfare state}

According to Beland and Petersen (2014), researchers in recent years have rightly complained about the vagueness of core concepts used in contemporary social policy debates, and have criticised the tendency among social policy students and practitioners to use the concept of 'welfare state' without offering any coherent definition of it. There are many problems in defining welfare states (for example, Briggs, 1961; Marshall, 1961; Wedderburn, 1965; Marwick, 1967; Therborn, 1983, 1984; Alber, 1988; Esping-Andersen, 1990; Lowe 1993; Wincott, 2001, 2011, 2013, 2014; Powell and Hewitt, 2002; Garland, 2014). According to Veit-Wilson (2000), many sources 'give some sort of brief nod to the need to define terms, usually following Humpty Dumpty, the patron genius of stipulative definitions'. For VeitWilson (2000) 'what criteria distinguish welfare states from non-welfare states' remained an unanswered question. The question of 'what is the welfare state?' was raised by Esping-Andersen (1990: 18). He stated that 'a remarkable attribute of the entire literature is its lack of much genuine interest in the welfare state as such' and studies 'have not asked the conceptual question ... when, indeed, is a state a welfare state. More recently, Garland (2014, p. 327) has asked 'What, in fact, is the welfare state?', adding that 'this long-standing question has once again become timely and important.'

A number of writers offered definitions of the welfare state (eg Briggs, 1961; 
Wedderburn, 1965; Marwick, 1967; Therborn, 1984; Alber, 1988; Lowe, 1993). However, many of these appear rather broad and vague, including phrases such as 'a state commitment of some degree', and fail Veit-Wilson's (2000) 'elementary test of discrimination and usefulness'. For example, 'A common textbook definition is that it involves state responsibility for securing some basic modicum of welfare for its citizens' (Esping-Andersen 1990, pp.18-19) has been dismissed as a bland and undiscriminating remark' (Veit-Wilson 2000).

Perhaps the most cited definition is that of Briggs (1961, p.228) who stated that a 'welfare state' is a state in which organized power is deliberately used in an effort to 'modify the play of market forces in at least three directions:

1. first, by guaranteeing individuals and families a minimum income irrespective of the market value of their work or their property (Table 1, Briggs 1);

2. second, by narrowing the extent of insecurity by enabling individuals and families to meet certain 'social contingencies' (for example, sickness, old age and unemployment) which lead otherwise to individual and family crises (Table 1, Briggs 2); and

3. third, by ensuring that all citizens without distinction of status or class are offered the best standards available in relation to a certain agreed range of social services' (in, for example, Marshall, 1961; Wedderburn, 1965; Woodroffe, 1968; Alber, 1988; Lowe, 1993; Veit-Wilson, 2000; Garland, 2014) (Table 1, Briggs 3).

Marshall (1961) considered that Briggs' phrase 'effort to modify' seems too weak, while Alber (1988) argued that a definition based on minimum standards is much too narrow, but a definition based on the 'deliberate use of state power to modify market forces' is too broad. Lowe (1993) commented that this definition had not wholly stood the test of time. Wedderburn (1965) noted that while there is a central core of agreement that the welfare state implies a state commitment of some degree which modifies the play of market forces in order to ensure a minimum real income for all, there is less agreement about whether the essential goal will also include the maintenance of full employment, economic growth or even ensuring that all citizens without distinction of status or class are offered the best standards available in relation to a certain agreed range of social service.' However, Briggs' definition does at least provide a starting point with multiple elements.

The importance of Britain in the welfare state debate should be noted. Britain arguably provided the term (for example, Briggs, 1961; Pierson, 2006, Garland, 2014: but see Wincott, 2011; Petersen \& Petersen, 2013). Briggs (1961, p. 223) writes that from Britain the phrase made its way round the world, but he points out that an insular debate where the 'uniqueness' of Britain has been emphasized to the neglect of the study of trends and tendencies in other countries. According to Wedderburn (1965), in the immediate post-war years the 'welfare state' was generally regarded as an almost exclusively British phenomenon. Nullmeier and Kaufmann (2010, p. 87) stated that the British welfare state reforms stand out in interpretations of the early 
post-war years (1945-50). According to Wincott (2011), contemporary commentators saw Britain as the original, exemplary and pre-eminent welfare state, which provided the 'Genesis story' associated with Archbishop Temple, and supplied the world with key concepts for welfare state theory such as Marshall's citizenship. Wincott (2013) points to the role of Britain in general welfare state narratives through being home to Keynes, Beveridge, and Attlee, and the scholarly significance of the English language. Wincott (2014) contends that Britain occupies a pivotal and peculiar position in the historiography of the welfare state, but the term does not appear in the Marshall essay, the Beveridge report (1942) or Temple's Christianity and the Social Order (1942), and only once in Temple's Citizen and Churchman (1941) (see also Petersen and Petersen, 2013). As Wincott (2011) and Garland (2014) point out, key analysts such as Titmuss and Marshall were late converts to its use and displayed considerable ambivalence about the term.

\section{Method and criteria}

Unclear definitions are compounded by different criteria and methods. Hicks (1999) differentiates between relatively qualitative, case-centred and historically intensive and highly quantitative, multivariate focus on spending. Ferrera (2008) states that different authors resorted to different methods for their comparisons, (the big divide being that between qualitative historical studies and quantitative statistical analyses), and adopted different approaches.

\section{Method}

Amenta (2002) differentiates four different methodological approaches to causal research, based on two axes of historical and comparative approach. Amenta and Hicks (2010) developed this $2 \times 2$ matrix, noting that each of the categories includes both quantitative and qualitative studies: comparative only studies; historical only studies; comparative and historical research (and neither historical nor comparative studies).

\section{Criteria/ Dimensions}

Different writers have suggested different numbers and content of criteria. As we can see below, the number of dimensions range from two to six. Most writers include social expenditure, but there appears to be little consensus beyond this 
although the introduction of social insurance, content or range of activities, and outcomes are mentioned by more than one writer.

Table 1 Number and content of criteria to identify the creation of welfare states

\begin{tabular}{|c|c|c|}
\hline Study & $\begin{array}{l}\text { Number of } \\
\text { Dimensions }\end{array}$ & Dimensions/ criteria \\
\hline Bonoli (1997) & 2 & $\begin{array}{l}\text { social expenditure as a percentage of GDP (how much); } \\
\text { percentage of social expenditure financed through } \\
\text { contributions (the how of welfare provision). }\end{array}$ \\
\hline Amenta (2002) & 2 & $\begin{array}{l}\text { the enactment of major social insurance programmes; } \\
\text { differences in the amount of social spending or 'efforts' } \\
\text { in social spending. }\end{array}$ \\
\hline $\begin{array}{l}\text { Green-Pedersen } \\
\text { (2004) }\end{array}$ & 2 & $\begin{array}{l}\text { policy definitions ((issues of content: which benefits or } \\
\text { services are provided); } \\
\text { outcome definitions. }\end{array}$ \\
\hline $\begin{array}{l}\text { Esping-Andersen } \\
\text { (1990) }\end{array}$ & 3 & $\begin{array}{l}\text { expenditure; } \\
\text { content; } \\
\text { theoretical selection of criteria. }\end{array}$ \\
\hline Pierson (2006) & 3 & $\begin{array}{l}\text { the first introduction of social insurance; } \\
\text { the extension of citizenship and the depauperization } \\
\text { of public welfare; } \\
\text { the growth of social expenditure. }\end{array}$ \\
\hline Alber (1988) & 5 & $\begin{array}{l}\text { target groups or the scope of public welfare programmes; } \\
\text { the range of state activities; } \\
\text { the quality of benefits and services, or minima versus } \\
\text { optima; } \\
\text { the (mix of) instruments utilized to realize the public } \\
\text { welfare tasks; } \\
\text { the method of financing public provisions, with different } \\
\text { emphases given to general revenues or earmarked fees. }\end{array}$ \\
\hline $\begin{array}{l}\text { Nullmeier and } \\
\text { Kaufmann (2010) }\end{array}$ & 6 & $\begin{array}{l}\text { the macro level of context factors; } \\
\text { social expenditure; } \\
\text { the internal structure of social programmes, the } \\
\text { generosity of social benefits, coverage, access etc; } \\
\text { the distribution of welfare production between state, } \\
\text { market, family and civil society, as well as governance } \\
\text { types of social policy; } \\
\text { the outcome of social policy interventions; } \\
\text { the public legitimation of social policy and the welfare } \\
\text { state. }\end{array}$ \\
\hline
\end{tabular}


All this suggests the presence of a 'dependent variable problem' (eg GreenPedersen 2004). Esping-Andersen (1990, p.18) states that

every theoretical paradigm must somehow define the welfare state .... We cannot test contending arguments unless we have a commonly shared conception of the phenomenon to be explained.

In other words, the explanatory cart has been placed before the definitional horse; it is premature to consider independent or explanatory variables without a clear dependent variable. As Pierson (1998, p. 557) put it,

One of the major barriers to cumulative research on contemporary welfare state reform is the absence of clear and compelling conceptualizations of the dependent variable.

However, Wincott (2001, fn) suggested that this reflected a deeper conceptual problem concerning the welfare state itself, while Green-Pedersen (2004) wrote that the 'dependent variable problem' was a problem of theoretical conceptualization rather than a problem of data.

Given that there is little consensus on the number or content of criteria of welfare states, the following sections focus on criteria that have been used in discussing the establishment of the British welfare state.

\section{Expenditure}

Most early studies and many comparative studies of welfare state development use the 'gold standard' of government social expenditure as a proportion of GNP or 'welfare effort' (Amenta, 2002; Bonoli, 1997; Green-Pedersen, 2004; Therborn, 1984). This measure has been heavily criticised by writers such as Esping-Andersen (1990) - but see Castles (2002).

\section{Legislation [Briggs 2]}

A number of studies focused on the year when key social legislation was implemented (for example,Flora \& Alber, 1981; Hicks, 1999; Pierson, 2006). However, it is unclear why the first (or second) adoption defines the welfare state. It could be argued that all measures (that is the final programme) are important. It is also unclear whether the sequence of legislation is important (see Kim, 2001).

\section{Content}

As noted above, it is unclear which benefits or services should be included in the content of welfare states (Green-Pedersen, 2004). For example, writers such as Heidenheimer (1981) stress the importance of education as an alternative to 'welfare'. Nor is it clear how a social insurance scheme for certain groups compares 
to comprehensive universal coverage. Finally, neither is it clear if maintenance of full employment, for example in the form of Keynesian demand management should be included (Wedderburn 1965).

\section{Social Citizenship and Social Rights [Briggs 3]}

According to Esping-Andersen (1990, p. 21), few can disagree with T. H. Marshall's ... proposition that social citizenship constitutes the core idea of a welfare state.' However, Powell (2002) pointed out that the problems of defining social rights have been clear since the original imprecise definition given by Marshall (1963, p. 74): the 'right to share to the full in the social heritage and to live the life of a civilised being according to the standards prevailing in the society' is the maximalist part of the citizenship range, with 'the right to a modicum of economic welfare and security' at the minimalist end. This leads to the problem of defining and operationalising social rights, which has been attempted in terms of 'de-commodification' (EspingAndersen, 1990), universality (Briggs, 1961; Marshall, 1961, ILO, 1950) and equality (Esping-Andersen (1990, p. 3).

\section{The Welfare State as the antithesis of the Poor Law}

A number of writers have stressed the importance of the welfare state as an alternative to or antithesis of the Poor Law (eg Marshall 1961; Briggs 1961). However, Harris (1996, pp. 124-125) argued that the Poor Law was a system of relief rooted not in contribution and contract, but in membership of the community. Poor relief was, in the last resort, available to all who needed it as a matter of citizen right

An armchair political theorist who analysed the two systems ... might conclude that ... it was the Poor Law that carried connotations of universality, communitarianism and citizenship, while it was social insurance that entailed exclusion, differentiation and limited contractual rights.

\section{The establishment of the welfare state in Britain.}

The varied criteria outlined above have been linked with a wide range of dates of establishment for the welfare state in Britain.

\section{The Old Poor Law (OPL)}

Some historians have detected the roots of the welfare state as far back as the sixteenth century. For example, Bruce (1968, p. 30) sees its origins in 'The Acte for the Releife of the Poore' of 1598. Woodroffe (1968) considers the 'taproot of the welfare state' to the 
Poor Law, which began in England in the sixteenth century as a comprehensive poor relief service based on destitution. She notes that the parliament of Elizabeth I created a system of social security, taking positive, constructive steps to prevent unemployment by creating work (with its most famous measure being the Statute of Artificers of 1563) and passing a Poor Law in 1601 to deal with any residue of unemployment. Blaug (1964, p. 229) termed the OPL 'a welfare state in miniature'). Szreter et al (2016) pointed out that the Elizabethan Poor Laws of 1598 and 1601 enshrined an absolute 'right of relief' for every subject of the Crown. They created a nationwide system of social security through a progressive community tax to fund provision at local level. While Poor Laws existed in many cities in early modern Europe, the English system was unique in its scale and geographical ubiquity, extending to every small rural parish. By the 1800s, England's Poor Law was transferring about 2\% of gross national product in support to the nation's poor in crisis years. Although modest by today's standards, this was the most generous such system in the world at that time. Solar (1995) argued that English poor relief post-1834 differed from most continental systems in terms of its uniformity and comprehensiveness; its source of finance of a local tax on income from property (while Continental poor relief was financed from a variety of sources: voluntary donations, income from capital, subsidies from local and national governments, and taxes), which allowed more redistribution; and its relative certainty and generosity.

Moreover, the Speenhamland system of 1795, in seeking to gear wages to the price of bread went far beyond the province of the Poor Law. (see for example, Block \& Somers, 2003). Esping-Andersen (1990, p. 36) cites Polanyi (1944) that the pre-industrial Speenhamland system of income security guaranteed a de facto social wage.

A number of writers have pointed to high level of expenditure both in terms of other European nations, and compared to later periods. According to Lindert (1994), Britain was a leader before 1834, appearing to have transferred a greater share of GNP to the poor and elderly than any other country. Somers and Block (2005) pointed out that England was unique among European countries in that it had a highly developed nationwide pre-industrial welfare system. Van Bavel and Rijpma (2015) stated that some 2.1-2.3 per cent of English GDP was redistributed through formalized poor relief for 1790, while the figure at the very peak of poor rates expenditures in 1818 may have been a percentage point higher. This may be compared to some 1.2-1.5 per cent for 1850, which was similar to the figures calculated for 1500 and 1700. They pointed out that while these totals may seem low by the standards of today's welfare states, the highest shares of GDP were as high as government social transfers would be until the twentieth century. Only from around 1930 would such transfers surpass these levels in North-West Europe. During the higher expenditure period, perhaps some 7-8 per cent of the population were covered, much higher than the 3-4 per cent found for 1500 and 1700, and the 5 per cent calculated for 1850 . 


\section{Nineteenth Century}

Saville (1957/8) stressed the origins of the welfare state in Victorian and Edwardian Britain. Writers appear to draw on three broad elements. The first is the New Poor Law (NPL) of 1834. Fraser (1984, p. 241) pointed to 'the absolutely central role of the Poor Law' which represented society's ultimate guarantee against destitution, its fiat was universal and its remit was comprehensive... yet the terms on which it offered relief were socially unacceptable. Marshall (1963, pp. 80-81) stated that the NPL treated the claims of the poor, not as an integral part of the rights of the citizen, but as an alternative to them - as claims which could be met only if the claimants ceased to be citizens in any true sense of the word, which has been termed the 'exclusionary principle of citizenship' by King and Waldron (1988) (but see Harris, 1996, above). Somers and Block (2003) termed 1834 a 'welfare revolution' which overturned an existing welfare regime by a market-driven one.

The second is state intervention and regulation, particularly the Factory Acts Marx and Engels (1966, Vol 2, p. 16) argued that the 'Ten Hours Bill' of 1847 was

not only a great practical success; it was the first time that in broad daylight the political economy of the middle class succumbed to the political economy of the working class.

Polanyi (1944) argued that 'social legislation, factory laws, unemployment insurance, and, above all, trade unions' have as their purpose the removal of human labour 'from the orbit of the market'. Esping-Andersen (1990, p. 44) cites Polanyi (1944) adding that the Factory Acts provided a degree of de-commodification. Briggs (1961) pointed out that the Factory Acts, notably the Ten Hours Act, marked a definite breach with laissez faire. Marshall (1963, pp. 80-81) considered that the Factory Acts initially narrowed the meaning of citizenship by applying to children and women exclusively, though by the end of the nineteenth century, such arguments had become obsolete, and the factory code had become one of the pillars of the edifice of social rights.

Woodroffe (1968) argued that the origins of England's welfare state must also be sought in the collectivism of the Victorian era (Polanyi 1944), but pointed out that the government took its first step in the field of industrial welfare before the Victorian era by passing the Health and Morals of Apprentices Act 1802 to limit the hours of work of apprentices in cotton mills. Woodroffe (1968) noted initiatives in education, public health, and 'municipal trading'. In short, in the Victorian period from 1837 to 1901, some of those social policies began which foreshadow England's welfare state. For example, in the field of public health, the Victorians from the 1850's onwards broke new ground, for in making vaccination the first free compulsory medical service provided by parliament on a national scale, they created 'a Victorian National Health Service' (Lambert 1962). Similarly, Pierson $(2004,2006)$ noted a substantial body of social reform from the Victorian era, including legislation 
on housing, public health and elementary education.

The third is broader administrative reform. Orloff and Skocpol (1984) note that for quite some time British historians have recognized the 'Victorian origins of the welfare state' in an administrative sense (for example, Roberts, 1960). Bruce (1968, p. 15) pointed to Sidney Webb as a 'pioneer of the welfare state'.

\section{Liberal Reforms (1906-1914)}

Much of this claim is based on social insurance legislation, which places the establishment of the British welfare state in the Liberal reforms of 1906-1914 [Table 1: Briggs 2]. According to De Swann (1988, p.149)

'the development of a public system of social insurance has been an administrative and political innovation of the first order, comparable in significance to the introduction of representative democracy.

Therborn (1984) claimed that a fairly non-controversial starting-point for the contemporary welfare state is the German social insurance legislation of the 1880s, beginning with the Health Insurance Act of 1883.

Flora and Alber (1981) noted that countries like Germany (1883), Norway (1909), Great Britain (1911) and the Netherlands (1913) were among the first countries in the world to introduce a compulsory health insurance scheme. Until the end of First World War, just two countries- United Kingdom and Denmark- adopted laws that covered all four risks of sickness, old age, accidents and unemployment, but with different sequences (cf Kim, 2001).

Pierson (2006) stated that the first introduction of social insurance is a widely used indicator of welfare state development. For Britain, he gives the dates of 1897 for industrial accident, 1911 for health, 1908 for pensions, 1911 for unemployment and 1945 for family allowances. Pierson (2004) suggested the date for the 'consolidation' of welfare states, using the year in which the second key social insurance measure was legislated, giving in a table 1897 (work injury) and 1908 (pensions) for Britain (although the 1908 pension was non-contributory). Pierson (2006) considered that dates for the growth of social expenditure in this period must be approached with especial caution, Although there is no critical threshold figure at which the welfare state may be said to have begun, Britain reached the figure of 3 per cent of GNP as a 'notional indicator of the origins of the welfare state' in 1905 (reaching 5 per cent by 1920) (p. 110, 113).

Kuhnle and Sander (2010) pointed to the early origins of welfare states in terms of social insurance. They noted that Britain was hailed as a pioneer in launching a 'modern welfare state' (Orloff and Skocpol 1984) since it had already instituted before World War I workers' compensation (1897), old age pensions (1908), health insurance (1911) and the 'world's first compulsory unemployment insurance' (1911). 
By 1911 Britain had surpassed Germany as a welfare state leader with more risks and larger parts of the population covered (Flora \& Alber 1981, p.55), and brought Britain to a par with Denmark at the top of the league of embryonic welfare states (p. 68).

Hicks (1999, p.44) suggested the Asquith government of 1906-14 in Britain provided a 'paradigm of Lib-Lab reform'. He used QCA to analyse programme adoption in terms of 'binding' (legally compulsory) and 'extensive and funded' measures (covering a notable share of potential target group). For Britain, the dates are 1908 (binding or extensive) and 1925 (binding/extensive) for old age, 1911 for sickness, 1897 (binding or extensive) and 1946 (binding/extensive) for workers' compensation, 1920 for unemployment compensation, and 1945 for family allowances.

Digby (1989, p. 41) noted the 'Edwardian social service state.' Fraser (1984, p.155) discussed 'Lloyd George and the origins of the welfare state'. Bruce (1968, p.154) noted the 'the turning point: social reform 1905-14.' However, Thane (1982, p. 83) pointed out the limited nature of reforms. For example, the 1908 pension was for the 'very poor, the very respectable and the very old'. Moreover, the Liberal reforms had 'no conscious grand design'.

\section{Inter-war period}

Digby (1989, p. 48) pointed to 'inter-war indeterminism', but noted evolution from the inter-war into the post-war period. According to Kuhnle and Sander (2010, p. 70), state social insurance and protection was extended in three ways in the interwar period: in terms of the scope of risks, in terms of the coverage of population, and through an increase in compulsory provision (Flora and Alber 1981). According to Orloff and Skocpol (1984) in 1919, a number of years after the initiation in Britain of all of the key programs of what would later come to be called a modern welfare state. Building upon pre-World War I foundations, during the 1920s Britain would become (according to a measure developed by Flora and Alber, 1981, p. 55) the world's leader in overall 'welfare state development'.

Pierson (2006, p. 114) regarded the first part of 'welfare states 1920-1975: the epoch of growth' as '1918-1940: consolidation and development' He continued that the period between the wars has often been described as a rather uneventful one for the welfare state, falling between the extensive innovations of the preceding twentyfive years and the period of remarkable growth immediately after 1945. Yet more recent commentators have tended to see the 1920s and 1930s as the seed-bed of post war welfare development (p. 119). This was the 'decisive epoch' in establishing the institutions and practices of that more interventionist form of government in which the postwar welfare state was grounded (p. 120).

Moreover, while the period between 1880 and 1920 is properly understood as the epoch of legislative innovation in the welfare state, it is only after 1920 that the fiscal consequences of these initiatives became clear (p. 120). British interwar social 
policy was dominated by the spectre of unemployment, but saw modest legislation on the social provision of housing and health care, education, contributory old age pensions, provision for widows and orphans and the steady 'break-up' of the Poor Law (p. 127).

\section{5}

Some writers point to the importance of the 'national minimum' [Briggs 1]. For example, Woodroffe (1968) pointed to the principle of the 'national minimum' of the Beveridge plan to provide for all its citizens protection from the 'cradle to the grave (Woodroffe 1968). Similarly, Marwick (1967) noted that in introducing the national insurance bill, Labour Minister James Griffiths claimed that it marked the beginning of the establishment of the 'principle of a National Minimum Standard'.

However, for others, it represented universality and the third element of the Briggs (1961) definition [Briggs 3]. Briggs (1961) noted that while the first two elements in his definition may be accomplished, in part at least, by what used to be called a 'social service state', the third objective, brings in the idea of the 'optimum' rather than the older idea of the 'minimum'. A 'quest for universality' was transforming the pre-war 'social service state' into some kind of 'welfare state' (Briggs 1961, p. 224; see also ILO 1950; Marshall 1961). Saville (1957/58) argued that the main contribution of these years was to make an extended range of social security benefits available to the whole population. As Fraser (1984, p. 207), put it, if the essential theme of the 1930s had been selectivity, that of the 1940s was universalism. Nullmeier and Kaufmann (2010, pp. 82-85) asked 'why 1945 as the starting point of a new phase?' They initially argued that 1945 and the early post-war years may be characterised as the period in which the welfare state became firmly entrenched. But this seemed less convincing with a view to the institutional dimension of the welfare state and the passage of social insurance legislation. The post-war era appeared to be the end of a phase in which the core set of social insurances was established in most continental European and Anglo-Saxon countries. Based on social expenditure, 1945 or 1950 did not appear to mark a rupture or discontinuity (cf Pierson 2006). However, 'despite these considerations and pieces of evidence, it seems appropriate to view 1945 as an important historical juncture'. The rationale appears to be the Beveridge 'universalistic reform model' and social rights. They contrasted 'selective' before the Second World War with 'universal' after 1945. Linked with 'equality', this shift expressed by the change in leading terms from 'social insurance' to 'social security' and from 'social policy' to 'welfare state'.

Marshall (1961) noted that the British Welfare State represented the very antithesis of the conception of the nineteenth century Poor Law where relief was directed not to the poor but to paupers, and took place right outside the market and in a manner which could not interfere with its working. Similarly, there was 
a significant difference between 1945 and the Liberal reforms. He cited a Lloyd George memorandum of 1911:

Insurance necessarily temporary expedient. At no distant date hope State will acknowledge full responsibility in the matter of making provision for sickness breakdown and unemployment [...] Gradually the obligation of the State to find labour or sustenance will be realized and honourably interpreted. Insurance will then be unnecessary (also cited by Digby, 1989, p. 46; Fraser. 1984, p. 168).

Marshall (1962, p. 295) noted that 'only in the National Health Service has this hope been fulfilled as yet.' In short, Marshall broadly suggests 1945, providing three reasons. First, the legislation of the 1940's finally dismantled the old three-tier system of the independent, the insured and the paupers. Second, the principles of comprehensiveness and universality rather than from the principle of a guaranteed subsistence. Subsistence, or the abolition of want, was the aim of the old system, to be achieved by insurance supplemented by the Poor Law, but universality was quite new. Third, the true symbol of the Welfare State was much more the National Health Service than social insurance, or even family allowances. King and Waldron (1988) add that the provision of education and health services in Britain conformed more closely to the model of citizenship rights than, say, the provision of supplementary benefits. In other words, even 1945 did not achieve a 'full' welfare state based on citizenship (see below).

Hicks (1999, p. 111) appears to see this period as 'midcentury consolidation': by 195010 of the 17 largest affluent capitalist democracies (including Britain) had implemented all five major types of income maintenance programme and had thereby consolidated firm programmatic foundations for subsequent welfare-state development. The year of consolidation was given as 1945 (p. 115), but this does not appear to relate to the underlying data (given as p. 51), and ignores 'in kind provision' (eg the NHS in 1946) as programme adoption for sickness relates to the 1911 National Health Insurance Act.

Digby (1989, p. 54) pointed to the 'classic welfare state' of 1948. Ferrera (2005, p. 54) stated that the 'first coherent and systematic architecture of a universalistic welfare state' was legislated between 1945 and 1948 in Britain. Fraser (1984) argued that the Beveridge Report was the 'nearest thing to a blueprint for a Welfare State which Britain had' (pp. xxi-xxii). He later stated that on 5 July 1948, the appointed day, the whole apparatus of what came to be called the Welfare State moved into operation (p. 237). The Beveridge Report has been 'conventionally been regarded as a principal blueprint of the welfare state' (Lowe 1993, p. 1). The scheme it advanced was 'in some ways a revolution, but in more important ways is a natural development from the past. It is a British revolution'. (Beveridge Report (1942, para 31). Marshall (1975, p. 84) stated that this transformation, or revolution, consisted in the welding together of the measures of social policy into a whole, so that the 'welfare state' denoted this new entity composed of old elements. Similarly, according to Jones and Lowe (2002, p. 5), the sum of the welfare legislation was greater than its individual 
parts. Peter Baldwin argued that the Report and its implementation can be seen as 'an historical event equivalent in importance and stature to the French or Russian Revolutions (in Jones and Lowe 2002, p. 4), providing three justifications: postwar governments adopted Beveridge's 'holistic' approach by accepting that economic and social policy should be complementary rather than antagonistic; the principle of universalism; and the principle of comprehensiveness.

Thane (1982, p. 255) stressed the full employment assumption of the Beveridge Report. She argued that universality of provision and a new attempt to manage the economy which constituted the claim of the post-war Labour governments to have established something qualitatively new, a new approach to the use of the power of the state consciously in the interests of social justice for the mass of the population, a 'welfare state'. (p. 267). Similarly, Pierson (2006, p. 28) stated that the development of Keynesian economic policy in associated with the promotion of an expanded welfare state- the so-called Keynesian Welfare State. In short, 'Beveridge + Keynes = Welfare State' (cf Wincott 2014).

\section{Later periods}

Esping-Andersen (1990, p. 23) suggested that 'welfare states are, in practice, of very recent date', noting key changes 'in almost all nations' during 'the late 1960s and early 1970s.' Wincott (2013) considered that writers such as Hicks (1999, pp. 153-155) noted a dramatic welfare expansion starting in the 1960s. Wincott continues that the range of social policy commitments - particularly in social services mostly focused on the non-working population (such as older people and childcare) - was also extended during the 1960s.

According to Ferrera (2008) the true novelty of the Trente Glorieuses was the spectacular expansion of this new institution of the welfare state. At the beginning of the 1950s social security expenditure was still below 10 per cent of GDP in most European countries. By the early 1970s many countries had come to pass the 20 per cent mark and most of the remaining ones had already surpassed 15 per cent. Therborn (1984) noted that it was around 1970 that the first welfare states appeared (in the sense of states) in which expenditures on welfare state activities - on income maintenance, care, education and so on, became predominant, with the three first (developed) welfare states being Belgium, Netherlands and Sweden. A change had taken place, completely overshadowing the immediate effects of World War II, Beveridge, and the tide of Social Democracy and Labourism.

Tomlinson (1998) argued that while the reforms of the welfare system under the 1945 Labour government are usually regarded as fundamental in creating the post-war welfare state, measured by their financial implications, and viewed in comparison with either pre-war Britain or other Western European countries in the same period, these reforms appeared strikingly limited. Far from bringing a 
'New Jerusalem', the 1940s reforms seemed to have brought into being an austere, minimalist structure of welfare provision. The striking feature of a comparison of British expenditure on welfare at the end of the Attlee government with the levels before the war is how small in real terms the increase was, especially, but by no means only, on transfer payments under National Insurance and National Assistance. However, his 1950 data on public spending on social welfare in Western Europe in 1950 (as \% of GDP) showed Britain close to the unweighted average of 9.4\%. Finally, as noted above, it can be argued that a 'full' citizenship-based welfare state has not yet been established (cf Marshall 1961; King and Waldron 1988).

\section{Multiple periods}

Some writers seem to hedge their bites, with multiple bites at the chronological cherry. For example, Saville (1957-8) wrote that in the twentieth century the legislative structure of the welfare state was carried through in three main periods of social reform: the Liberal government of 1906-1914; WWI and the inter-war years; and the Labour government 1945-50. Similarly, Digby (1989, p. 29) considered that state intervention in British social policy significantly increased in three main periods: the 1830s and 1840s (NPL of 1834); the Edwardian period and the 1940s, when universality in provision was seen as a crucial ingredient in welfare provision

Putting all these claims together, it can be seen that there are over 20 different accounts of the establishment of the British welfare state (Table 2) that arrive at rather varying conclusions as they draw on different (often implicit) criteria, methods, and evidence.

Table 2: Method, criteria and evidence for different periods of the creation of the British welfare state.

\begin{tabular}{|l|l|l|l|}
\hline \multicolumn{1}{|c|}{ Period } & \multicolumn{1}{|c|}{ Method } & \multicolumn{1}{c|}{ Criteria } & \multicolumn{1}{c|}{ Evidence } \\
\hline $\begin{array}{l}\text { Old Poor } \\
\text { Law }\end{array}$ & $\begin{array}{l}\text { Historical } \\
\text { study of } \\
\text { Britain }\end{array}$ & $\begin{array}{l}\text { 'Right of relief' } \\
\text { [Briggs 3?] }\end{array}$ & $\begin{array}{l}\text { Comprehensive relief (Woodroffe 1968; } \\
\text { Bruce 1968); 'welfare state in miniature' } \\
\text { (Blaug 1964) }\end{array}$ \\
\hline $\begin{array}{l}\text { Old Poor } \\
\text { Law }\end{array}$ & Comparative & Expenditure & $\begin{array}{l}\text { High expenditure in English OPL } \\
\text { compared to other countries and later } \\
\text { in NPL (Van Bavel and Rijpma 2015); } \\
\text { Szreter et al 2016) }\end{array}$ \\
\hline $\begin{array}{l}\text { Old Poor } \\
\text { Law }\end{array}$ & Comparative & $\begin{array}{l}\text { Coverage of } \\
\text { population }\end{array}$ & $\begin{array}{l}\text { High coverage of population (Van Bavel } \\
\text { and Rijpma 2015) }\end{array}$ \\
\hline
\end{tabular}




\begin{tabular}{|c|c|c|c|}
\hline $\begin{array}{l}\text { Nineteenth } \\
\text { Century }\end{array}$ & $\begin{array}{l}\text { Historical } \\
\text { study of } \\
\text { Britain }\end{array}$ & New Poor Law & $\begin{array}{l}\text { Universal and comprehensive, but relief } \\
\text { on socially unacceptable terms (Fraser } \\
\text { (1984:241); claims of poor as alternative } \\
\text { to citizenship (Marshall (1963: 80-81); } \\
\text { 'exclusionary principle of citizenship' } \\
\text { (King and Waldron 1988); 'welfare } \\
\text { revolution' which overturned an existing } \\
\text { welfare regime by a market-driven one. } \\
\text { (Somers and Block 2003). }\end{array}$ \\
\hline $\begin{array}{l}\text { Nineteenth } \\
\text { Century }\end{array}$ & $\begin{array}{l}\text { Historical } \\
\text { study of } \\
\text { Britain }\end{array}$ & $\begin{array}{l}\text { State } \\
\text { intervention } \\
\text { and regulation, } \\
\text { particularly the } \\
\text { Factory Acts }\end{array}$ & $\begin{array}{l}\text { De-commodification (Polanyi 1944; } \\
\text { Esping-Andersen 1990); 'definite breach } \\
\text { with laissez faire' (Briggs 1961); } \\
\text { later part of social rights (Marshall 1963: } \\
\text { 80-81) }\end{array}$ \\
\hline $\begin{array}{l}\text { Nineteenth } \\
\text { Century }\end{array}$ & $\begin{array}{l}\text { Historical } \\
\text { study of } \\
\text { Britain }\end{array}$ & Legislation & $\begin{array}{l}\text { Legislation on housing, public health } \\
\text { and elementary education (Woodroffe } \\
\text { 1968; Pierson 2004, 2006). }\end{array}$ \\
\hline $\begin{array}{l}\text { Nineteenth } \\
\text { Century }\end{array}$ & $\begin{array}{l}\text { Historical } \\
\text { study of } \\
\text { Britain }\end{array}$ & $\begin{array}{l}\text { Broader } \\
\text { administrative } \\
\text { reform }\end{array}$ & $\begin{array}{l}\text { 'Victorian origins of the welfare state' } \\
\text { (Roberts, 1960; Orloff and Skocpol } \\
\text { 1984). }\end{array}$ \\
\hline $\begin{array}{l}\text { Liberal } \\
\text { Reforms }\end{array}$ & Comparative & Social insurance & $\begin{array}{l}\text { Social insurance; coverage of risks (Flora } \\
\text { and Alber 1981; Hicks 1999; Kim 2001; } \\
\text { Pierson 2004, 2006; Kuhnle and Sander } \\
\text { 2010) }\end{array}$ \\
\hline $\begin{array}{l}\text { Liberal } \\
\text { Reforms }\end{array}$ & Comparative & $\begin{array}{l}\text { Social } \\
\text { Expenditure }\end{array}$ & $\begin{array}{l}\text { Britain reached the figure of } 3 \text { per cent } \\
\text { of GNP as a 'notional indicator of the } \\
\text { origins of the welfare state' in } 1905 \\
\text { (Pierson 2006) }\end{array}$ \\
\hline $\begin{array}{l}\text { Liberal } \\
\text { Reforms }\end{array}$ & $\begin{array}{l}\text { Historical } \\
\text { study of } \\
\text { Britain }\end{array}$ & Various/ unclear & $\begin{array}{l}\text { 'Edwardian social service state.' (Digby } \\
\text { (1989: 41); 'Lloyd George and the origins } \\
\text { of the welfare state' (Fraser (1984: 155); } \\
\text { 'the turning point: social reform 1905- } \\
\text { 14' (Bruce (1968: 154) } \\
\text { However, Thane (1982: 83) pointed out } \\
\text { the limited nature of reforms with 'no } \\
\text { conscious grand design'. }\end{array}$ \\
\hline $\begin{array}{l}\text { Inter-war } \\
\text { period }\end{array}$ & Comparative & Various & $\begin{array}{l}\text { Evolution, and state social insurance } \\
\text { and protection (Flora and Alber 1981; } \\
\text { Kuhnle and Sander 2010) }\end{array}$ \\
\hline
\end{tabular}




\begin{tabular}{|c|c|c|c|}
\hline $\begin{array}{l}\text { Inter-war } \\
\text { period }\end{array}$ & $\begin{array}{l}\text { Historical } \\
\text { study of } \\
\text { Britain }\end{array}$ & $\begin{array}{l}\text { Various: } \\
\text { expenditure; } \\
\text { legislation; and } \\
\text { break-up of } \\
\text { Poor Law }\end{array}$ & $\begin{array}{l}\text { Fiscalconsequences of pre-warinitiatives } \\
\text { became clear; modest legislation on the } \\
\text { social provision of housing and health } \\
\text { care, education, contributory old age } \\
\text { pensions, provision for widows and } \\
\text { orphans and the steady 'break-up' of the } \\
\text { Poor Law (Pierson 2006) }\end{array}$ \\
\hline 1945 & $\begin{array}{l}\text { Historical } \\
\text { study of } \\
\text { Britain }\end{array}$ & $\begin{array}{l}\text { National } \\
\text { Minimum } \\
\text { [Briggs 1] }\end{array}$ & $\begin{array}{l}\text { 'National minimum' in Beveridge Report } \\
\text { (Woodroffe 1968) and in national } \\
\text { insurance bill (Marwick 1967). }\end{array}$ \\
\hline 1945 & $\begin{array}{l}\text { Historical } \\
\text { study of } \\
\text { Britain }\end{array}$ & $\begin{array}{l}\text { Universality } \\
\text { [Briggs 3] }\end{array}$ & $\begin{array}{l}\text { Universality (ILO 1950; Saville 1957/58; } \\
\text { Briggs 1961; Marshall 1961; Fraser } \\
\text { 1984); Beveridge 'universalistic reform } \\
\text { model', social rights and equality } \\
\text { (Nullmeier and Kaufmann (2010) }\end{array}$ \\
\hline 1945 & $\begin{array}{l}\text { Historical } \\
\text { study of } \\
\text { Britain }\end{array}$ & $\begin{array}{l}\text { Antithesis of } \\
\text { Poor Law }\end{array}$ & Marshall (1961) \\
\hline 1945 & Comparative & $\begin{array}{l}\text { Consolidation } \\
\text { of social } \\
\text { insurance } \\
\text { measures }\end{array}$ & $\begin{array}{l}\text { Implementation of all five major types } \\
\text { of income maintenance programme } \\
\text { (Hicks 1999) }\end{array}$ \\
\hline 1945 & $\begin{array}{l}\text { Historical } \\
\text { study of } \\
\text { Britain }\end{array}$ & $\begin{array}{l}\text { Coherent } \\
\text { blueprint and } \\
\text { Appointed Day }\end{array}$ & $\begin{array}{l}\text { 'Classic welfare state' (Digby 1989); 'first } \\
\text { coherent and systematic architecture of } \\
\text { a universalistic welfare state' (Ferrera } \\
\text { 2005); blueprint of Beveridge Report } \\
\text { (Fraser 1984; Lowe 1993); 'Appointed } \\
\text { Day' (Fraser 1984; Lowe 1993); old } \\
\text { elements woven together into new } \\
\text { whole (Marshall (1975); sum of the } \\
\text { welfare legislation was greater than its } \\
\text { individual parts (Jones and Lowe 2002) }\end{array}$ \\
\hline 1945 & $\begin{array}{l}\text { Historical } \\
\text { study of } \\
\text { Britain }\end{array}$ & $\begin{array}{l}\text { Keynesian } \\
\text { welfare } \\
\text { state; full } \\
\text { employment }\end{array}$ & $\begin{array}{l}\text { Full employment assumption of } \\
\text { the Beveridge Report (Thane 1982); } \\
\text { Keynesian economic policy (Pierson } \\
\text { 2006) }\end{array}$ \\
\hline $\begin{array}{l}\text { Later } \\
\text { periods }\end{array}$ & Comparative & $\begin{array}{l}\text { Social } \\
\text { expenditure }\end{array}$ & $\begin{array}{l}\text { Later expansion of social expenditure } \\
\text { (Therborn 1984; Hicks 1999; Ferrera } \\
\text { 2008; Wincott 2013). }\end{array}$ \\
\hline
\end{tabular}




\begin{tabular}{|l|l|l|l|}
\hline $\begin{array}{l}\text { Later } \\
\text { periods }\end{array}$ & $\begin{array}{l}\text { Historical } \\
\text { study of } \\
\text { Britain }\end{array}$ & $\begin{array}{l}\text { Social } \\
\text { expenditure }\end{array}$ & $\begin{array}{l}\text { Austere welfare state in 1945; no } \\
\text { significant increase in expenditure } \\
\text { (Tomlinson 1998) }\end{array}$ \\
\hline $\begin{array}{l}\text { Later } \\
\text { periods }\end{array}$ & $\begin{array}{l}\text { Historical } \\
\text { study of } \\
\text { Britain }\end{array}$ & $\begin{array}{l}\text { Citizenship- } \\
\text { based welfare } \\
\text { state [Briggs 3] }\end{array}$ & $\begin{array}{l}\text { A 'full' citizenship-based welfare state } \\
\text { has not yet been established (cf Marshall } \\
\text { 1961; King and Waldron 1988). }\end{array}$ \\
\hline
\end{tabular}

\section{Conclusion}

We can now return to the main questions raised earlier. This article has explored when the welfare state was established in Britain, with the extant literature suggesting a number of possible creation periods (Old Poor Law; nineteenth century; Liberal reforms; inter-war period; 1945; later periods). It argues that we need to be aware of the multiple, often unclear and sometimes implicit definition of the welfare state. We also need to consider the many competing methods and criteria used in exploring the establishment of the British welfare states (expenditure; legislation; content; social citizenship; antithesis of the Poor Law).

Esping-Andersen (1990: 1-2) stated that the welfare state has been approached both narrowly and broadly. This suggests that we might choose a broad or narrow definition, but Green-Pedersen (2004) concluded that no definition of the welfare state is a priori better or worse than others. Alber (1988) argued that there was no such thing as the idea of the welfare state; but rather a host of concepts accompanied by different types of institutional arrangements. Writers such as Bonoli (1997) and Castles (2002) have suggested the need for multiple dimensions and a variety of measures to take into account the multidimensional nature of social policy. However, as we have over 20 different possible combinations, it is very difficult to come to a clear conclusion that the British welfare state was created in a particular period due to specific criteria. As seen in Table 2, the greatest number of dimensions suggest 1945 as the creation period. Moreover, if forced to focus on one dimension, a good case can be made for 'Briggs 3', which also suggests 1945. Briggs (1961) noted that while the first two elements in his definition may be accomplished, in part at least, by what used to be called a 'social service state', the third objective, brings in the idea of the 'optimum' rather than the older idea of the 'minimum' (see also Marshall 1961). As Lowe (1993) put it, the third element was really the distinctive characteristic of a welfare state. A 'quest for universality' was transforming the pre-war 'social service state' into some kind of 'welfare state' (Briggs 1961: 224; see also ILO 1950; Marshall 1961). This article is the first to attempt to review the literature as to what criteria suggest which creation period for the British welfare state. However, while the strongest case and the greatest 
number of dimensions suggest 1945, in the words of T H Marshall (1961): 'we may still be in doubt what was the exact combination of circumstances in Britain in the 1940's which evoked that cry of 'Eureka!', and what precisely they were pointing at when they were emitting it.

\section{References}

Alber, J. (1988) Continuities and changes in the idea of the welfare state. Politics and Society, 16, 4, 451-468

Amenta, E. (2002) What we know about the development of social policy: comparative and historical research in comparative and historical perspective. in J. Mahoney and D. Rueschemeyer (Eds.) Comparative Historical Analysis: Achievements anaAgenda. Cambridge: Cambridge University Press (pp. 154-82)

Amenta, E. and Hicks, A. (2010) Research methods. in F. Castles, S. Leibfried, J. Lewis, H.Obinger, and C. Pierson (Eds.) The Oxford Handbook of the Welfare State. Oxford: Oxford University Press (pp.105-120)

Beland, D. and Petersen, K. (2014) Introduction. in D. Beland and K. Petersen (Eds.) Analysing Social Policy Concepts and Language. Bristol: Policy Press (pp.1-11)

Beveridge Report (1942) Social Insurance and Allied Services. (Cmd. 6404) London : HMSO Blaug, M., (1964) The poor law report reexamined'. Journal of Economic History, 24, 229-243

Block, F. and Somers, M. (2003) In the shadow of Speenhamland: Social policy and the old poor law. Politics and Society, 31, 2, 283-323

Bonoli, G. (1997) Classifying welfare states: A two-dimension approach. Journal of Social Policy, 26, 351-372

Briggs, A. (1961) The welfare state in historical perspective. European Journal of Sociology, 2, 2, 221-58

Bruce, M. (1968) The Coming of the Welfare State. (4th ed.) London: Batsford

Castles, F. (2002) Developing new measures of welfare state change and reform. European Journal of Political Research, 41, 613-641

De Swaan, A. (1988) In Care of the State. Health care, education and welfare in Europe and the USA in the modern era. Cambridge: Polity

Digby, A. (1989) British Welfare Policy Workhouse to Workfare. London: Faber and Faber. Esping-Andersen, G. (1990) The Three Worlds of Welfare Capitalism. Cambridge: Polity Press Ferrera, M. (2005) The Boundaries of Welfare. European Integration and the new Spatial Politics of Social Protection. Oxford: Oxford University Press

Ferrera, M. (2008) The European welfare state: Golden achievements, silver Prospects, West European Politics, 31, 1-2, 82-107

Flora, P. and Alber, J. (1981). Modernization, democratization and the development of welfare states in Western Europe. in P. Flora and A. Heidenheimer (Eds.) The Development 
of Welfare States in Europe and America, New Brunswick, NJ: Transaction Books (pp. 37-80)

Fraser, D. (1984) Evolution of the British Welfare State. (2nd ed) Basingstoke: Macmillan

Garland, D. (2014) The Welfare state: A fundamental dimension of modern government. European Journal of Sociology, 55, 3, 327-364

Green-Pedersen, C. (2004) The dependent variable problem within the study of welfare state retrenchment. Journal of Comparative Policy Analysis: Research and Practice, 6, 1, 3-14

Harris J (1996) 'Contract' and 'Citizenship' in D. Marquand and A. Seldon (Eds) The Ideas That Shaped Pos -War Britain. London: Fontana

Heidenheimer, A. (1981) Education and social security entitlements in Europe and America. in P. Flora and A. Heidenheimer (Eds.) The Development of Welfare States in Europe and America, New Brunswick, NJ: Transaction Books (pp. 269-305)

Hicks, A. (1999) Social Democracy and Welfare Capitalism, Ithaca: Cornell University Press I.L.O. (1950) International Labour Conference, 34th Session, Objectives and Minimum Standards of Social Security'

Jones, M. and Lowe, R. (2002) From Beveridge to Blair. The first fifty years of britain's welfare state 1948-98, Manchester: Manchester University Press

Kim, K-s (2001) Determinants of the timing of social insurance legislation among 18 OECD countries, International Journal of Social Welfare, 10: 2-13

King, D. and Waldron, J. (1988) Citizenship, social citizenship and the defence of welfare provision, British Journal of Political Science, 18, 415-443

Kuhnle, S. and Sander, A. (2010) The emergence of the western welfare state. in F. Castles, S. Leibfried, J. Lewis, H. Obinger, and C. Pierson (Eds.) The Oxford Handbook of the Welfare State. Oxford: Oxford University Press (pp. 61-80)

Lambert, R. (1962.) A Victorian National Health Service: State vaccination 1855-7, Historical Journal, 5, 1, 1-8

Lindert, P. (1994) The rise of social spending, 1880-1930. Explorations in Economic History, 31: 1- 37

Lowe, R. (1993) The Welfare State in Britain since 1945. Basingstoke: Macmillan

Marshall, T. H. (1961) The welfare state: A sociological interpretation, European Journal of Sociology, 2, 2, 284-300

Marshall, T.H. (1963) Sociology at the Crossroads. London: Heinemann

Marshall, T. H. (1975),Social Policy. London

Marwick, A. (1967) The Labour party and the welfare state in Britain 1900-1948, American Historical Review, 73, 2, 380-403

Marx, K. and Engels, F. (1966) Selected Works in Three Volumes, Moscow

Nullmeier, F. and Kaufmann, F-X. (2010) Post-war welfare state development. in F. Castles, S. Leibfried, J. Lewis, H. Obinger, and C. Pierson (Eds.) The Oxford Handbook of the Welfare State. Oxford: Oxford University Press (pp. 81-101)

Orloff, A. S., and Skocpol, T. (1984) Why not equal protection? Explaining the politics of public social spending in Britain, 1900-1911, and the United States, 1880s-1920, American Sociological Review, 726-750 
Petersen, K. and Petersen, J. (2013) Confusion and divergence: Origins and meanings of the term 'welfare state' in Germany and Britain, 1840-1940. Journal of European Social Policy, 23, 1, 1-15

Pierson, C. (2004) Late Industrializers and the Development of the Welfare State. Social Policy and Development Programme, United Nations Research Institute for Social Development

Pierson, C. (2006) Beyond the Welfare State? (3 ${ }^{\text {rd }}$ ed.) Polity Press: Cambridge

Pierson, P. (1998) Irresistible forces, immovable objects: Post-industrial welfare states confront permanent austerity. Journal of European Public Policy, 5, 539-560

Polanyi, K. (1944) The Great Transformation. New York: Rinehart.

Powell, M. (2002) The hidden history of social citizenship. Citizenship Studies, 6, 3, 229-244

Powell, M. and Hewitt, M. (2002) Welfare State and Welfare Change. Buckingham: Open University Press

Roberts, D. (1960) Victorian Origins of the Welfare State. New Haven: Yale University Press

Saville, J. (1957-8) The welfare state: an historical approach, New Reasoner, 3,

Solar P. (1995). Poor relief and English economic development before the Industrial Revolution. Economic History Review, 48: 1-22

Somers, M. and Block, F. (2005) From poverty to perversity: Ideas, markets, and institutions over 200 years of welfare debate, American Sociological Review, 70, 260-287

Szreter, S., Kinmonth, A, Kriznik, N., and Kelly, M. (2016) The art of medicine Health, welfare, and the state-the dangers of forgetting history. Lancet, 388, December 3,, 2734-5

Temple, W. (1941) Citizen and Churchman. London: MacMillan

Temple, W. (1942). Christianity and the Social Order. London: Penguin

Thane, P. (1982) Foundations of the Welfare State. London: Longman

Therborn, G. (1983) When, how and why does a state become a welfare state?' Presented at the ECPR Joint Workshops in Freiburg, March 20-25

Therborn, G. (1984) Classes and states: Welfare state developments, 1881-1981. Studies in Political Economy, 14

Tomlinson, J. (1998) Why so austere? The British welfare state of the 1940s. Journal of Social Policy, 27, 1, 63-77

Van Bavel, B. and Rijpma, A (2015) How important were formalized charity and social spending before the rise of the welfare state? A long-run analysis of selected western European cases, 1400-1850, Economic History Review, 1-29

Veit-Wilson, J. (2000) States of welfare: A conceptual challenge. Social Policy and Administration, 34, 1, 1-25

Wedderburn, D. (1965), Facts and theories of the welfare state. in R. Miliband and J. Saville (Eds.) The Socialist Register 1965. London: Merlin Press (pp. 127-146) Wincott, D. (2001) Reassessing the social foundations of welfare (state) regimes. New Political Economy, 6, 3, 409-25

Wincott, D. (2011) Images of welfare in law and society: The British welfare state in 
comparative perspective. Journal of Law and Society, 38, 3, 343-75

Wincott, D. (2013). The (golden) age of the welfare state: Interrogating a conventional wisdom, Public Administration, 91, 4, 806-822

Wincott, D. (2014) Original and imitated or elusive and limited? Towards a genealogy of the welfare state idea in Britain. in D. Beland and K. Petersen (Eds.) Analysing Social Policy Concepts and Language. Bristol: Policy Press (pp.127-141)

Woodroffe, K. (1968) The making of the welfare state in England. Journal of Social History, $1,4,303-324$ 